\title{
Corporate Real Estate in Malaysian Higher Learning Environment
}

\author{
Mohd Fauzee Musa, Zarita Ahmad @ Baharum \\ Faculty of Architecture Planning \& Surveying, \\ Universiti Teknologi MARA, Malaysia \\ fauzeemusa@yahoo.com, saniahzaki@salam.uitm.edu.my
}

\begin{abstract}
Corporate Real Estate (CRE) is regarded as a part of strategic management in the organization. It is attempted to create awareness and highlight the important of implementing CRE in the educational institution. Educational institution is now facing a challenging task of producing quality human capital and providing students with condusive environment that will enhance their learning, becoming more creative and match the service delivery. Thus, to achive all this any educational institution has to adopt strategy that will help them to add values and enhance their competitiveness. This research is to investigate the components of CRE that create added value to the core business.
\end{abstract}

Keywords: Corporate real estate, Public University; added value

eISSN 2514-751X @ C 2018. The Authors. Published for AMER ABRA cE-Bs by e-International Publishing House, Ltd., UK. This is an open access article under the CC BY-NC-ND license (http://creativecommons.org/licenses/bync-nd/4.0/). Peer-review under responsibility of AMER (Association of Malaysian Environment-Behaviour Researchers), ABRA (Association of Behavioural Researchers on Asians) and CE-Bs (Centre for EnvironmentBehaviour Studies), Faculty of Architecture, Planning \& Surveying, Universiti Teknologi MARA, Malaysia.

DOI: https://doi.org/10.21834/aje-bs.v3i7.258 


\subsection{Introduction}

The Corporate Real Estate Plan highlights how the University approaches the management of the built and natural environment to ensure existing assets and potential future assets are managed effectively across their life cycle. The key focus areas to manage real estate assets are (i) provide an assetbase that matches and supports the business needs of the University;(ii) consolidate existing corporate capital assets and optimising asset utilisation;

(iii) meet statutory compliance obligations; and (iv) align asset operating costs with business planning and service delivery requirements. Thus, it is essential that the awareness and understanding of CRE is embedded in every educational institution as the benefits are evident.

Educational Institution relies on these assets to deliver teaching and research programs and the cost of owning and using these assets is one of the highest outlays for the institution. With property assets representing nearly $80 \%$ of the value of the total assets, the buildings, whether used for office space, teaching and research programs or simply storage, incur significant capital and recurrent costs. The way in which the institution uses and manages space is therefore a key factor in the efficient application of the resources at its disposal. If not used and managed effectively the cost of these assets will be a drain on available funds. Thus, to address this the institution need to implement a CRE framework the principles of which embody: (i) integrating asset planning with institution business planning process; (ii) exposing the full costs of assets in delivery of teaching and research programs; (iii) assigning organisational responsibility and accountability for assets; and (iv) rationalising the methods of delivering asset and facility management services.

\section{Problem Statement}

Educational institution is now facing a challenging task of producing quality human capital and providing students with condusive environment that will enhance their learning, becoming more creative and match the service delivery. Thus, to achive all this any educational institution has to adopt strategy that will help them to add values and enhance their competitiveness. CRE is aimed at proving organization to add values and reduce risk/costs. The issue is what are the components of CRE that can help them to achieve this.

Implementation of CRE in the corporate business organization is common thing, because their awareness on the profitability is much higher (Roulac, 2001). But in the educational institution it is very limited. This research is attempted to create awareness and highlight the important of implementing CRE in the university's real estates and facilities.

\section{Objectives}

This paper objective is to investigate the components of CRE that create added value to the core business of the public universities.

\section{Significant of study}

CRE concept has proven to be successful in other organizationareas such as hospitality (MichealD., 1991), organization(Varcoe, 2000), industry (Liow K., 2008). However, practice and implementation in the educational institution is very limited. Creating awareness and the 
advantage of this concept will hopefully add values, strengthening the image and fulfilling the occupiers needs based on their requirement and service delivery strategy.

\subsection{Literature Review}

\section{Corporate Real Estate}

Corporate Real Estate (CRE) refers to the land and buildings owned by companiesnot primarily in the real estate firms are investing significantly in properties that are used for operational purpose (Kim and Joseph, 2004). Corporate real estate as defined by Ranko Bond (1995) is CRE covers the entire range of activities concerning portfolio of building and land holding held by an organization, investment planning and management, financial planning and management, construction planning and management and facilities planning and management. The concept of corporate real estate brings together all the perspectives typical for real Estate: financial, occupational, and those linked to business strategy and management, which have typically been looked at separately in traditional real estate management.

A corporate real estate (CRE) portfolio can be viewed from three perspectives: 1) as a financial asset of the corporation; 2) as a real Estate market asset; and 3) as an operational asset (factor of production). A significant number of corporations deal with each of these perspectives separately and rarely seek to manage all of them together for the greater good of the organisation (Varcoe, 2000).

That means that the main objective of the corporate real estate is to support the business operation which is the management of all aspects of realestate, acquisitionanddevelopment, disposition, property management, financial analysis, surplus property and miscellaneous activities such as leasing and brokerage.

\section{Public Universities in Malaysia}

The governance of all Malaysian universities comes under a common legislative framework of the 1971 Universities and University College Act. University's in this country as changed after the amendment made in the Universities and University College Act 1971 in 1996 where complexity has increased in accordance with evolution of university corporatisation.

The public universities were corporatized by governance only and not financially. The corporatized universities are required to raise revenues from market related activities. Some of the strategic plan that corporatized universities use to seek revenues include research grant and consultancy, franchise educational programs, the renting out of university facilitiesand recruitment of full-fee-paying foreign students.

Universities play an important role in national development in term of economic growth, political development, socialcultural transformation. But the link between universities and national development is not a one- way relationship, for while the university can shape society, it, in turn, is shaped by society. 


\section{The Importance of CRE to Organization}

CRE in an organization can be by an individual or by a separate unit. Itmay also be completely outsourced to an external provider. Depending on how the CRE function is organized and CRE decisions are made, the CRE function may be centralised, (standardised process, decisions and outcomes by the head office) or decentralised with individual offices and operations having their own processes and objectives (Veale, 1989).

The importance of CRE to organization it is to manage the property that cover the entire range of activities concerning portfolios of buildings and land holding, investmentplanning and management, financial planning and management, construction planning and management and facilities planning and management. CRE is concern to establish and maintain a close match between an organization's business and property strategies.

\section{Component of Added Value to Corporate Real Estate}

Corporate real estate main objective is to produce return from property without changing the head branch of a business and the corporate real estate management is able to make a contribution for the securing and strengthening of the competitiveness of a business, means that real estate offers lots of possibilities. Strategies and methods of corporate real estate management should make a contribution that business objectives will be supported and finally reached better, company-owned resources will be used more intensively, costs will be reduced and synergy potentials will be shown. The objective is an increasing profitability of the business.

In the context of higher education, corporate real estate is not being well studied or applied because the stigma of corporate real estate usually goes to business corporation or organization which involved in the profit making (Manning, 1999). Corporate real estate should be implemented in the universities because it is dealing with physical assets that is used to operationalise their core businesses. The concept of corporate real estate would enhance the strategic process, planning, control and also increasing the efficiency of the property or facilities usage in contributing to thecore university activities (Amaratunga D., 2000). By enhancing the value and competitiveness, the quality of education can be improved with a better image for the university itself.

Various studies have investigated CRE components that add values to organization namely De Jonge (1996), Roulac (2001) and Lindholm (2008). De Jonge (1996) studied the contributing to the transformation of real estate from mere "cost of doing business" to a true corporate asset and come up with 7 components of CRE. In addition Raulac (2001) focus towards on corporate property strategy and revealed 8 components of CRE. Lindholm (2008) studied the value added by corporate real estate on firm and organization and produced 7 components of CRE. Table 1 below summarized the findings.

From the analysis, there are 4 components that similar between from the components added values various studies which are on decreasing cost, increase value, increase flexibility and promotion marketing and sales. Increase productivity only found in studies by De Jonge, 1996 and Lindholm, 2008. Although there are 3 components from Roulac, 2001 and 2 components from Lindholm, 2008 are not similar to the other studies. The criteria that are not similar from Roulac, 2001 to the others studies is promote human resource objective; 
faciltitate production, operation and service delivery; and facilitate management process \& knowledge. 2 components from Lindholm, 2008 that are not similar also is participating in strategic process and increasing innovations and the 2 components from De Jonge, 1996 that are not similar is on risk control and changing the culture.

Table 1. Components of Added Value for Corporate Real Estate by various studies

\begin{tabular}{|c|c|c|c|}
\hline Studies/year & \multirow[t]{2}{*}{ De Jonge (1996) } & \multirow[t]{2}{*}{ Roulac (2001) } & \multirow[t]{2}{*}{ Lindholm (2008) } \\
\hline Criteria & & & \\
\hline Cost & Cost Reduction & cupancy cost & Decreasing cost \\
\hline Increase productivity & Increasing Productivity & $X$ & Increasing productivity \\
\hline Risk decrease & Risk Control & $X$ & $X$ \\
\hline Increase value & Increase of value & $\begin{array}{l}\text { Capture the real estate value } \\
\text { creation of business }\end{array}$ & hg value of assets \\
\hline Increase flexibility & Increase of flexibility & Increase flexibility & Increasing flexibility \\
\hline Changing culture & Changing the culture & $X$ & $X$ \\
\hline marketing \& sales & motion and marketing & $\begin{array}{l}\text { Promote marketing message, } \\
\text { sale \& selling process }\end{array}$ & y marketing \& sales \\
\hline $\begin{array}{l}\text { Promote human resource } \\
\text { objective }\end{array}$ & $x$ & $\begin{array}{l}\text { Promote Human Resource } \\
\text { Objective }\end{array}$ & $X$ \\
\hline $\begin{array}{l}\text { Facilitate production, operation, } \\
\text { and service delivery }\end{array}$ & $x$ & $\begin{array}{l}\text { Facilitate production, operation, } \\
\text { and service delivery }\end{array}$ & $X$ \\
\hline $\begin{array}{c}\text { Facilitate management process \& } \\
\text { knowledge work }\end{array}$ & $X$ & $\begin{array}{c}\text { Facilitate management process } \\
\text { \& knowledge work }\end{array}$ & $X$ \\
\hline Participating in strategic process & $X$ & $X$ & Participating in strategic process \\
\hline Increasing innovations & $x$ & $X$ & Increasing innovations \\
\hline
\end{tabular}

As a result of systematic comparison, there are certain components are similar or bring the same concept. There is a components are too much alignment to the business operation which not too implementable for the university at certain parts. Finally, figure 1 and the description below will consist of selected components which combined from above framework 
and have been related to the university. The selected component value added that possible to be implement when CRE suitable applied in educational institution are as follows:-

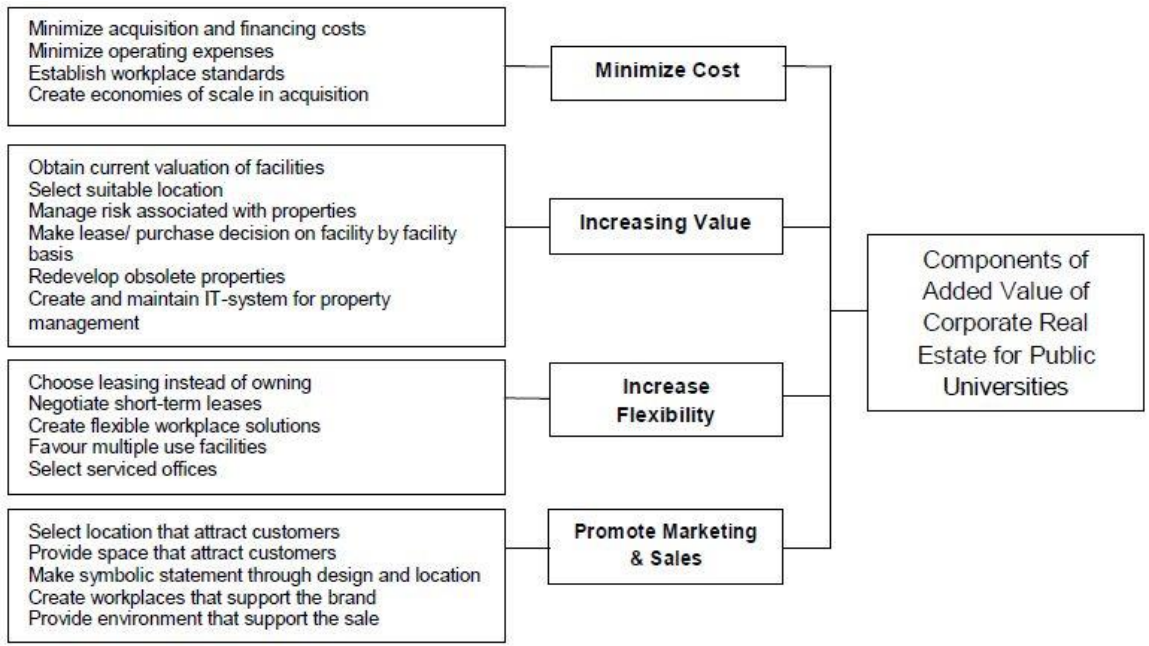

Figure 1: Components of Added Value of Corporate Real Estate for Public Universities

Minimization cost - the objective to seek for a lower occupancy cost and this is to look for option to minimize the occupancy cost and also promote the cost effective for the space usage. Lindholm (2008), by reducing cost in any area may give impact on the financial performance of the organization. The arrangement for the buildings and facilities in the university must meet the requirements and at the same time achieve the cost aspects.

Capture the Real Estate Value Creation - according to Nourse \& Roulac (1993), when a well recognized organization starts its operation at one place, basically it creates a value to that area because it suddenly makes people come to that area as well as attracting other businesses. With a good strategy and location factor, the value of property at that area will gradually increases in parallel with the demand which also benefiting the organization itself.

Increase Flexibility - according to Nourse and Roulac (1993), concept of the flexibility is the design of the property, where specific building design may not suitable for any other activities. Flexibility is how the occupancy term took place in an occupancy period, which is short or long term and it is important to avoid an excess cost for the unnecessary longer occupancy at certain place Lindholm, 2008). Building with specific design for specific usage will be less flexible compared to the ordinary building design.

Promote Marketing Message - relating to how the property of one organization could function as advertisement tool and attract peoples' attention. Property can be an effective tool 
for promotion because people easy to recognize the organization that comes with an excellent appeared image, facilities, as well as atmosphere provided (Lindholm, 2008). Buildings in universities can be very big promotional tools because it may show its caliber as a quality education centre to the public.

\subsection{Conclusion}

The concept of corporate real estate brings together all the perspectives typical for real estate: financial, occupational, and those linked to business strategy and management, which have typically been looked at separately in traditional real estate management. The issue in regards to the educational institution is, they are now facing a challenging task of producing quality human capital and providing students with condusive environment that will enhance their learning, becoming more creative and match the service delivery. Thus, to achive all this any educational institution has to adopt strategy that will help them to add values and enhance their competitiveness.

\section{References}

Amaratunga D. and Baldry, D., (2000) Assessment of facilities management performance in higher education properties, Facilities, 18:7/8, 293-301

Bon, R. (1995), "Corporate real estate management practices in Europe and the United States: 1993 and 1994", Facilities, Vol. 13 No.7, pp.10-16.

Kooymans, R. (2000), "The outsourcing of corporate real estate management - how do corporate real estate units and outsource service providers view each other and management issues?", paper presented at Pacific Rim Real Estate Society Conference, Sydney, January, pp.1-13.

Krumm, P., Dewulf, G., and Jonge, H. de (2000) What is Corporate Real Estate? in, G. Dewulf, P. Krumm, and H. de Jonge (ed.), Successful Corporate Real Estate Strategies, ARKO Publishers.

Lindholm, A. L. (2008). A constructive study on creating core business relevant CREM strategy and performance measures. Facilities, Vol. 26 (No. 7/8), pp. 343-358.

MalaysiaUniversitiesand UniversityCollegesAct1971 (Act30)(Amendmentsup to 1 January 2006). Malaysia: Malayan Law Journal Sdn. Bhd \& Percetakan Nasional Malaysia Berhad.

Manning, C., and Roulac, S. E. (1999) 'Corporate Real Estate Research Within The Academy', Journal of Real Estate Research, Volume 17, No 3, pp. 265-279.

Nourse, H. O., \& Roulac, S. E. (1993). Linking Real Estate Decisions to Corporate Strategy. The Journal of Real Estate Reseach, Vol. 8 (No. 4), Pg.475-494.

Roulac,(2001)Corporatepropertystrategyisintegraltocorporatebusinessstrategy, JRER, Vol.22, Nos. 1/2

Varcoe, B. (2000) 'A Process for The Portfolio Management of Real Estate Assets'bJournal of Corporate Real Estate, Volume 2, No 2, 2000, pp 113-122.dd 